\title{
IDH1 Gene Mutation
}

National Cancer Institute

\section{Source}

National Cancer Institute. IDH1 Gene Mutation. NCI Thesaurus. Code C118389.

A change in the nucleotide sequence of the IDH1 gene. 